\title{
ObSERVAÇÕes SOBRE A META FinAl Do MOdo DE FAZER FILOSOFIA DE LUDWIG WITTGENSTEIN
}

\author{
REMARKS ON LUDWIG WITTGENSTEIN'S WHOLE AIM IN HIS WAY OF DOING PHILOSOPHY \\ Gustavo Augusto Fonseca Silva \\ Universidade Federal de Minas Gerais, BRASIL \\ fonsecaugusto@hotmail.com
}

\begin{abstract}
In The Principles of Mechanics, physicist Heinrich Hertz argues that instead of replying to the question "what is force?" like physicists and philosophers had been doing unsuccessfully, Newtonian physics should be reformulated without considering "force" a basic concept. Decades after Hertz's book, Ludwig Wittgenstein considered the physicist's proposal a perfect model for how philosophical problems should be solved, to the point that he made it the foundation of his way of doing philosophy. This article addresses Wittgenstein's way of doing philosophy, while it also proposes the reason why he failed in solving the philosophical problems - as did Hertz in his project on reformulating Newtonian physics without considering the concept "force". And to illustrate Wittgenstein's failure, it examines his disputes with mathematicians Kurt Gödel and Alan Turing on the foundations of mathematics.
\end{abstract}

Keywords: Ludwig Wittgenstein $\bullet$ method by examples $\bullet$ complete clarity $\bullet$ Heinrich Hertz - Kurt Gödel • Alan Turing. questões seria uma fanfarronice desavergonhada, e uma presunção tão extravagante, que se perderia com isso toda confiança."

Kant 2013 [1781/1787], B 504

\section{Introdução}

Há décadas os estudiosos da obra de Ludwig Wittgenstein vêm analisando a influência exercida pelas ideias do físico alemão Heinrich Hertz na formulação tanto de sua primeira quanto de sua segunda filosofia (e.g. Barker, 1980; Janik, 1994; Simões, 2012, 2013). Porém, como de costume em se tratando da exegese dos textos de Wittgenstein, é difícil encontrar algum consenso entre os wittgensteinianos sobre a natureza e o alcance de tal influência. Assim, por exemplo, se de um lado há pesquisadores como Joachim Schulte (1992) que tendem a minimizar a relevância de Hertz 
para a compreensão do Tractatus logico-philosophicus, por outro existem estudiosos como James Griffin (1964) que argumentam que a teoria pictórica do significado, a pedra angular do Tractatus, tem suas raízes justamente em Hertz. Mais recentemente, outra controvérsia particularmente interessante envolvendo o papel de Hertz no desenvolvimento das ideias de Wittgenstein surgiu com a publicação em 2008 do artigo "Hertz, Wittgenstein and philosophical method" por John Preston. Nele, Preston investiga a alegação feita por alguns wittgensteinianos de que a concepção metodológica de Wittgenstein em sua filosofia tardia é tributária de Hertz. Conforme Preston (p.48), nós tendemos atualmente a ler Hertz à luz de Wittgenstein, sobretudo a sua preocupação em clarificar o conceito de força, e acabamos por distorcer o seu pensamento. "(Hertz) 'clarifica' o conceito de força apenas em um sentido especial, não congênito com as atitudes filosóficas maduras de Wittgenstein", ${ }^{1}$ afirma Preston (p.49). Não obstante isso, Preston pondera que "é claro que a concepção de Wittgenstein da meta (aim) da filosofia foi influenciada pela concepção de Hertz" (p.50) e que "os dois pensam que certos problemas (...) conceituais importantes são questões de falta de clareza" (p.50.). Levando a termo essa linha de raciocínio, Preston declara categoricamente: "A meta (aim), tanto para Hertz como para Wittgenstein, é clareza conceitual completa, o desaparecimento completo de tormentos filosóficos" (p.50).

Para respaldar essa afirmação, Preston cita a famosa passagem do Big Typescript em que Wittgenstein revela: "A meta final do meu modo de fazer filosofia é conferir a uma expressão uma forma tal que certas inquietudes desapareçam (Hertz)" 2 (apud Monk 1995, p.397). ${ }^{3}$ Referindo-se a essa anotação de Wittgenstein, seu biógrafo Ray Monk comenta que a menção a Hertz se deve ao fato de ele ter proposto em Os princípios da mecânica que, em vez de responder diretamente à pergunta "o que é força?", como vinham tentando fazer físicos e filósofos, seria melhor reformular a física newtoniana sem usar "força" como um conceito básico. "Quando essas excruciantes contradições são removidas", escreveu Hertz (1984 [1894], p.9 apud Monk 1995, p.38), "a questão da natureza da força não terá sido resolvida; mas nossa mente, não mais exasperada, deixará de fazer-se perguntas improcedentes." Segundo Monk (1995, p.397), Wittgenstein achava a solução de Hertz um modelo perfeito de como dissipar a confusão filosófica e nela se baseia seu modo de fazer filosofia. "Wittgenstein sabia de cor esta passagem de Hertz e costumava citá-la para descrever sua própria concepção dos problemas filosóficos e a maneira correta de resolvê-los”, observa Monk (1995, pp.38-9). "(...) sua meta foi sempre resolver tais contradições e substituir confusão por clareza."

Apesar de compartilhar com Monk a interpretação de que Hertz e Wittgenstein buscam clareza conceitual, Preston acredita que "alegações de que a concepção tardia de Wittgenstein do método filosófico foram fortemente influenciadas pelo procedimento de pensamento de Hertz são (...) injustificadas" (2008, p.65). Para fundamentar essa conclusão, Preston analisa minuciosamente o "procedimento de pensa- 
mento" que Hertz apresenta nos Princípios da mecânica e o contrasta com as Investigações filosóficas de Wittgenstein, revelando suas divergências. Trata-se, claro, de uma discussão fascinante que nenhuma pessoa interessada na influência de Hertz em Wittgenstein deveria ignorar. Neste artigo, porém, essa questão específica será deixada de lado em favor do exame de um ponto ainda mais relevante para a avaliação da segunda filosofia wittgensteiniana: o fato de Wittgenstein não ter conseguido "substituir confusão por clareza" em seu intuito de dissolver os problemas filosóficos. Em outras palavras, o objetivo central deste trabalho é mostrar, com base em ideias defendidas por autores com os quais Wittgenstein dialoga em sua obra e em ideias defendidas pelo próprio Wittgenstein, como e por que ele não atingiu, nem poderia mesmo atingir, a meta final do seu modo de fazer filosofia - assim como Hertz não atingiu, nem poderia mesmo atingir, a clareza conceitual completa em seu sistema, no qual a propósito não deixou de empregar o conceito de força (Jammer 2011, pp.279-80) e "pressupôs outras coisas invisíveis por trás daquelas que víamos, 'aliados ocultos, fora dos limites de nossos sentidos"' (Jammer 2011, p.277).

A fim de facilitar a exposição, este texto foi dividido em três seções, além desta introdução e das considerações finais. Na segunda seção, avalia-se o método por exemplos de Wittgenstein, com o qual ele pretendia obter a clareza completa e assim resolver de vez os problemas filosóficos. De acordo com Wittgenstein, em vez de buscar a essência definidora dos conceitos, como Sócrates demandava de seus interlocutores, caberia aos filósofos dar exemplos dos conceitos para responder às questões tradicionais da filosofia, como "O que é o conhecimento?”, “O que é a amizade?", "O que é o justo?”. Ao elaborar esse método, porém, como será detalhado adiante, Wittgenstein desconsiderou que diferentes pessoas podem dar diferentes exemplos de um conceito, sendo impossível decidir objetivamente quais são os exemplos certos e quais são os exemplos errados. Por isso, dar exemplos dos conceitos não afastaria as dificuldades, como almejava Wittgenstein. Em seguida, na terceira seção, passase à discussão de mais um obstáculo que impediu Wittgenstein de atingir a clareza completa: o fato, ressaltado por inúmeros teóricos e pelo próprio Wittgenstein, de que nossos conceitos não têm limites fixos e a linguagem é irremediavelmente vaga. Sendo assim, diferentes pessoas usam e compreendem as palavras de maneiras diferentes, o que muitas vezes resulta em enganos, mal-entendidos e incompreensão - problemas com os quais, como se verá, Wittgenstein sofreu até o fim da vida, a despeito de seu método filosófico. Posteriormente, na quarta seção, explicitam-se as disputas entre Wittgenstein e os matemáticos Kurt Gödel e Alan Turing a respeito dos fundamentos da matemática. A finalidade desse relato é deixar patente que o método por exemplos não levou Wittgenstein à clareza completa nem lhe garantiu realmente "um lugar de verdadeiro repouso", como ele afirmou ter encontrado no início dos anos 1930 (Monk 1995, p.271). 


\section{Um método para fazer filosofia}

Após ter reconhecido, no fim dos anos 1920, que não havia de fato resolvido de vez os problemas filosóficos, como havia declarado no prefácio do Tractatus logicophilosophicus, Wittgenstein decide voltar para Cambridge, Inglaterra, a fim de se tornar efetivamente "o terminus ad quem da grande filosofia ocidental" (Wittgenstein 2010a, p.58). Com esse intuito, e em franca oposição à concepção filosófica do Tractatus, Wittgenstein passa a defender na década de 1930 que, em vez de ensinar doutrinas e desenvolver teorias, como ele havia feito em seu livro de 1921, caberia ao filósofo demonstrar uma técnica, um método para chegar à clareza (Monk 1995, p.271). Convencido de que dessa forma poderia dissolver os problemas filosóficos, Wittgenstein declararia já em outubro de 1930, na aula inaugural de seu curso de filosofia na Universidade de Cambridge, que tinha obtido "uma concepção clara do método correto em filosofia" (Monk 1995, p.272): "O nimbo da filosofia se perdeu. Pois agora temos um método para fazer filosofia, e podemos falar de filósofos hábeis. Compare-se a diferença entre alquimia e química: a química possui um método e nós podemos falar de químicos hábeis" (1995, p.272).

No $§ 133$ das Investigações filosóficas, Wittgenstein apresenta de forma simples e direta o seu método para fazer filosofia, isto é, o seu método por exemplos:

(... ) a clareza à qual aspiramos é na verdade uma clareza completa. Mas isto significa apenas que os problemas filosóficos devem desaparecer completamente.

A verdadeira descoberta é a que me torna capaz de romper com o filosofar, quando quiser. - A que acalma a filosofia, de tal modo que esta não seja mais fustigada por questões que colocam ela própria em questão. - Mostrase agora, isto sim, um método por exemplos, e a série desses exemplos pode ser interrompida. - Resolvem-se problemas (afastam-se dificuldades), não um problema.

Wittgenstein "sustentou que seu 'novo método' de fazer filosofia constituiu uma 'guinada' no 'desenvolvimento do pensamento humano', comparável à revolução promovida por Galileu na ciência" (Glock 1998, p.163). Mais que isso: Wittgenstein sustentou que seu método por exemplos, que ele certa vez disse ser exatamente oposto ao de Sócrates (Monk 1995, p.305), levaria à clareza completa, com a qual ele acreditava que os problemas filosóficos desapareceriam completamente. Hoje, porém, quase 90 anos depois da declaração triunfal de Wittgenstein em sala de aula, parece evidente que ele não havia de fato obtido uma concepção clara do método correto em filosofia. Muito menos que o nimbo da filosofia havia se perdido. $E$ isso não surpreende se for levado em conta que o método por exemplos jamais poderia ser eficaz pelo fato de que diferentes pessoas dão diferentes exemplos de um conceito, sem 
haver um modo de decidir objetivamente quais são os exemplos certos e quais são os exemplos errados. Uma explicação dessa dificuldade elementar se encontra no livro O reino de Deus está em vós, de Liev Tolstoi, um dos autores que Wittgenstein mais admirava (Monk 1995, p.115). Ao refletir sobre questões relativas ao bem e ao mal, Tolstoi observa que "nenhuma definição humana pode fazer que aquilo que uns consideram o mal seja considerado pelos demais como tal" (Tolstoi 2011, p.72) e que "não há, nem pode haver, uma autoridade externa que dê uma definição do mal que seja reconhecida por todos" (2011, p.74). O mesmo entrave, é claro, apresenta-se ao método por exemplos de Wittgenstein, já que também não há, nem pode haver, uma autoridade externa que dê exemplos do conceito de mal, assim como de qualquer outro conceito, que sejam reconhecidos por todos.

Curiosamente, em uma aula de 1938, Rush Rhees apontou esse problema a Wittgenstein, que o descartou como sem importância:

[Rhees fez a Wittgenstein uma pergunta sobre a sua 'teoria' da deterioração.]

Pensam que tenho uma teoria? Pensam que estou a dizer aquilo que a deterioração é? Aquilo que faço é descrever diferentes coisas a que se chama deterioração. Poderia concordar com a deterioração - "A vossa bela cultura musical é ótima, mas estou muito contente que as crianças já não tenham de aprender harmonia." [Rhees: Será que aquilo que diz não implica uma preferência por certos modos de usar 'deterioração'?] Muito bem, se se quiser, mas isso, já agora - não, não tem importância. O meu exemplo de deterioração é um exemplo de uma coisa que conheço, talvez de uma coisa de que não gosto — não sei. 'Deterioração' aplica-se à pequena parte das coisas que é possível que eu saiba (Wittgenstein 2009, pp.29-30).

Aquilo que Wittgenstein dizia implicava uma preferência por certos modos de usar "deterioração" e é lógico que isso tem importância. O exemplo de deterioração de Wittgenstein é um exemplo de uma coisa que ele conhecia, talvez de uma coisa de que não gostava - não sei. "Deterioração" aplicava-se à pequena parte das coisas que é possível que ele soubesse. Mas também é possível que ele não soubesse. Um fato que Wittgenstein desconsiderou ao elaborar seu método por exemplos, assim como ao refletir sobre seguir regras. "Nosso uso da linguagem é como jogar um jogo de acordo com as regras" (Wittgenstein 2001, p.32), disse Wittgenstein a seus alunos em mais uma aula do início dos anos 1930. Em certo sentido, é esse mesmo o caso, como aliás já havia afirmado Fritz Mauthner no monumental Beiträge zu einer Kritik der Sprache, que Wittgenstein conhecia desde a juventude (Janik e Toulmin 1991, p.140 e p.273). No entanto, as regras "sempre admitem interpretações divergentes" (Pears 1973, p.171). Em especial as regras do uso da linguagem. Aparentemente sem considerar isso, Wittgenstein escreveu no §54 das Investigações filosóficas:

Dizemos que se joga segundo esta ou aquela regra, porque um observador pode ler essas regras nas práxis do jogo (...). - Mas como o observador 
distingue, nesse caso, entre um erro de quem joga e uma jogada certa? Há para isso indícios no comportamento dos jogadores.

Mas como o observador distingue, no uso das palavras "bem", "mal" e "deterioração", entre um erro de quem fala e um uso certo? Há para isso indícios no comportamento dos falantes? Além do mais, quem seria a autoridade externa que distinguiria, no uso dessas palavras, entre um erro de quem fala e um uso certo? E quem seria a autoridade externa que ensinaria às pessoas o uso certo das palavras "bem", "mal" e "deterioração" até a clareza completa? "Pois não pertence ao seguir uma regra a técnica (a possibilidade) de treinar o outro nela? E por meio de exemplos, ademais. E o critério de sua compreensão há de ser a coincidência das ações individuais (...)" (Wittgenstein 1987, VII, §53). Portanto, quem usasse as palavras "bem", "mal" e "deterioração" sem coincidência com Wittgenstein não teria compreendido a regra? Quem usasse as palavras "bem", "mal" e "deterioração" sem coincidência com Wittgenstein cometeria um erro? Indiferente a dificuldades dessa natureza, Wittgenstein afirma no §219 das Investigações filosóficas: "Quando sigo a regra não escolho. Sigo a regra cegamente". De fato, quando sigo a regra de um jogo, não escolho. Sigo a regra cegamente. Mas que regra seguir cegamente no uso das palavras "bem", "mal" e "deterioração"? E que regra seguir cegamente no uso das demais palavras? Que regra seguir cegamente no uso da palavra "bom”, por exemplo? “É bom porque Deus assim o ordenou' é a expressão correta para a ausência de fundamento" (Wittgenstein 2010a, p.65), anotou Wittgenstein em seu diário no início dos anos 1930. Ateus como Bertrand Russell jamais seguiriam a mesma regra no uso da palavra "bom" muito menos cegamente. Cometeriam, portanto, um erro?

Sem levar em conta que não há, nem pode haver, uma autoridade externa que dê exemplos dos conceitos que sejam reconhecidos por todos e que as regras do uso da linguagem sempre admitem interpretações divergentes, Wittgenstein convida no $\S 66$ das Investigações filosóficas:

Considere, por exemplo, os processos que chamamos de "jogos". Refiro-me a jogos de tabuleiros, de cartas, de bola, torneios esportivos etc. O que é comum a todos eles? Não diga: "Algo deve ser comum a eles, senão não se chamariam 'jogos"', - mas veja se algo é comum a eles todos. — Pois, se você os contempla, não verá na verdade algo que fosse comum a todos, mas verá semelhanças, parentescos, e até toda uma série deles. Como disse: não pense, mas veja! - Considere, por exemplo, os jogos de tabuleiro, com seus múltiplos parentescos. Agora passe para os jogos de carta: aqui você encontra muitas correspondências com aqueles da primeira classe, mas muitos traços comuns desaparecem e outros surgem. Se passarmos agora aos jogos de bola, muita coisa comum se conserva, mas muitas se perdem. - São todos "recreativos"? Compare o xadrez com o jogo da amarelinha. Ou há em todos um ganhar e um perder, ou uma concorrência entre os jogadores? Pense nas paciências. Nos jogos de bola há um ganhar e um perder; mas se uma criança 
atira a bola na parede e a apanha outra vez, este traço desapareceu. Veja que papéis desempenham a habilidade e a sorte. E como é diferente a habilidade no xadrez e no tênis. Pense agora nos brinquedos de roda: o elemento de divertimento está presente, mas quantos dos outros traços característicos desapareceram! E assim podemos percorrer muitos, muitos outros grupos de jogos e ver semelhanças surgirem e desaparecerem.

Considere agora o que chamamos de "ciência". Martin Heidegger, por exemplo, afirma em Ser e tempo, publicado em 1927, que, "em geral, pode-se definir a ciência como o todo de um conjunto de fundamentação de proposições verdadeiras" (p.47), mas logo admite: "Essa definição não é completa nem alcança o sentido de ciência". Em vista disso, Heidegger apresentaria outra definição desse conceito em um curso ministrado em 1929: "A ciência existe onde há institutos nos quais, com a ajuda do aparato técnico, são realizadas investigações" (Heidegger 2009, p.44). No entanto, sabendo que essa nova definição também não é completa nem alcança o sentido de ciência, Heidegger prontamente observa, antecipando-se às "semelhanças de família" wittgensteinianas (Wittgenstein 2008, p.45):

Talvez esse enunciado seja válido para todas as ciências naturais e para a medicina, mas não para as ciências humanas. E como se dão as coisas em relação à ciência da música, que computamos às ciências históricas? Ela também possui institutos e até mesmo "instrumentos" como o cravo e o piano. Entretanto, esses instrumentos possuem uma função completamente diversa do que, por exemplo, um eletroscópio ou um termômetro. No fundo, porém, todas as ciências necessitam de instrumentos técnicos - mesmo que sejam apenas livros. A ciência está impressa em livros. É certo que o livro possui na filologia uma função diversa do código civil na ciência do direito ou da bíblia na teologia. É questionável se com esse instrumento, com os livros — de qualquer modo não são todos os livros que se mostram como instrumentos —, a essência da ciência é caracterizada (Heidegger 2009, p.44).

Mais à frente, Heidegger retoma a discussão sobre o que é ciência e apresenta uma terceira definição desse conceito: "Ciência é conhecimento metódico, sistemático, exato e universalmente válido" (2009, p.45). Mas pondera:

Justamente os dois últimos predicados valem desde sempre como determinações insignes da ciência. As pessoas reportam-se frequentemente a Kant, que disse certa vez: "Afirmo, contudo, que em toda doutrina particular da natureza só se consegue encontrar tanta ciência propriamente dita quanto se puder encontrar aí matemática". Uma ciência só é científica na medida em que for matematizável. Dessa forma, as ciências humanas de modo algum são ciências, uma vez que se opõem por princípio à matematização. Por outro lado, a matemática se mostra como a ciência propriamente dita, pois é de fato a mais exata das ciências e seus resultados são, de modo puro e simples, universalmente válidos (Heidegger 2009, p.45). 
Wittgenstein, por sua vez, seguindo regras diferentes das de Heidegger, não considerava a matemática uma ciência propriamente dita, mas sim uma série de técnicas, sem verdades a descobrir (Wittgenstein 2003, p.297; Monk 1995, p.298). Mas a matemática, para Heidegger (2006, p.45) "a ciência aparentemente mais rigorosa e de estrutura mais sólida", é uma ciência ou não? E o direito? E a teologia? E a história? E a música? E as ciências humanas são realmente científicas? Para responder a essas perguntas, é necessário responder à pergunta fundamental: o que é ciência? Uma pergunta intocada pelo método por exemplos. Uma pergunta que "foi frequentemente formulada pelos gregos. Ela é uma questão antiga, ou seja, uma questão sempre nova. Ela constitui uma daquelas questões que não se aquietam quando dela já temos à mão uma definição" (Heidegger 2009, p.28). Mais: ela constitui uma daquelas questões que não se aquietam quando dela só temos à mão exemplos. Sem perceber isso, Wittgenstein pergunta-se no $\$ 69$ das Investigações filosóficas:

Como explicaríamos a alguém o que é um jogo? Creio que lhe descreveríamos jogos, e poderíamos acrescentar à descrição: "isto e outras coisas semelhantes chamamos de 'jogos”'. E nós próprios sabemos mais? Será que apenas a outrem não podemos dizer exatamente o que é um jogo? - Mas isto não é ignorância. Não conhecemos os limites, porque nenhum está traçado.

E como explicaríamos a alguém o que é ciência? Creio que, seguindo o método wittgensteiniano, lhe descreveríamos exemplos, e poderíamos acrescentar à descrição: "isto e outras coisas semelhantes chamamos de 'ciência". Mas entre esses exemplos deveríamos incluir ou não a matemática? E o direito, a teologia, a história, a música e as ciências humanas? Sem enfrentar esse tipo de problema, Wittgenstein retoma no \$71 das Investigações filosóficas a questão de como explicar o que é um jogo e afirma:

(... ) exatamente assim explica-se o que é um jogo. Dão-se exemplos e querse que eles sejam compreendidos num certo sentido. - Mas com essa expressão não quero dizer que essa pessoa deva ver agora nesses exemplos o algo em comum que eu - por alguma razão - não posso exprimir. Mas sim que tal pessoa deva agora empregar esses exemplos de um determinado modo. A exemplificação não é aqui um meio indireto de elucidação, — na falta de outro melhor. Pois toda elucidação geral pode também ser mal compreendida. Eis como jogamos o jogo. (Refiro-me ao jogo de linguagem com a palavra "jogo".)

De acordo com Wittgenstein, exatamente assim explica-se o que é ciência. Dãose exemplos e quer-se que eles sejam compreendidos num certo sentido e que se empreguem esses exemplos de um determinado modo. Wittgenstein, no entanto, desconsiderou o fato de que diferentes pessoas dão diferentes exemplos e os empregam de diferentes modos, sem haver uma autoridade externa que distinga entre um 
exemplo errado e um exemplo certo. Eis como jogamos o jogo. (Refiro-me ao jogo de linguagem com a palavra "ciência".)

Sem se deter, porém, nessas dificuldades, Wittgenstein estendeu seu novo método filosófico à estética. Assim, nos anos 1930, Wittgenstein passou a defender que, em vez de ensinar doutrinas e desenvolver teorias sobre o belo, caberia ao filósofo explicitar a beleza de uma obra de arte, explicando-a. Isto é, para Wittgenstein, em vez de teorias, é necessário "dar uma explicação que seja aceita. Este é o propósito da explicação" (Monk 1995, p.364). Mas quem poderia explicitar a beleza de uma obra de arte, explicando-a? Quem poderia dar uma explicação que fosse aceita? Julian Bell, aluno de Cambridge nos anos 1930, não teria a menor dúvida sobre quem Wittgenstein teria em mente, como ironizou neste poema:
Pois (Wittgenstein) enuncia disparates, muitas afirmações faz,/ Sempre o seu voto de silêncio a quebrar;/ De ética, estética, fala dia e noite,/ E designa as coisas de boas ou más, ou certas e erradas./ (...) Quem, sobre qualquer assunto, já viu/ Ludwig refrear-se de estabelecer a lei? / Em qualquer compa- nhia ele grita e manda calar,/ Interrompe nossas frases e balbucia as suas;/ Discute sem cessar, severo, irado, vociferante,/ Certo de estar com a razão, e de estar certo orgulhoso,/ Tais defeitos são comuns, partilhados por todos em parte,/ Mas Wittgenstein pontifica sobre Arte (Monk 1995, p.237).

Certo de que seria a pessoa que daria uma explicação que fosse aceita, e de ser essa pessoa orgulhoso, Wittgenstein desconsiderou em estética que explicitar a beleza de uma obra de arte implica uma preferência e isso, é claro, tem importância. Musicalmente, por exemplo, a preferência de Wittgenstein restringia-se a seis compositores: Haydn, Mozart, Beethoven, Schubert, Brahms e Labor (Monk 1995, p.23). Obviamente, seria ingênuo acreditar que alguma explicação da música de compositores que Wittgenstein detestava, como Mahler e Schönberg (Monk 1995, p. 83), poderia convencê-lo, já que "suas opiniões sobre a maioria dos assuntos era absoluta, não permitindo argumentos" (Pascal 1984, p.17). Também seria ingênuo acreditar que uma explicação dos textos de Shakespeare poderia convencer Wittgenstein, que confessou: "Tenho uma profunda desconfiança perante a maior parte dos admiradores de Shakespeare" (Wittgenstein 1992a, p.123). Na verdade, Wittgenstein tinha uma profunda desconfiança perante a maior parte dos admiradores de muitos dos escritores mais prestigiados de seu tempo, como Rainer Maria Rilke e T. S. Eliot (Bouwsma 2005, p.118). Além disso, Wittgenstein tinha uma profunda desconfiança perante outras culturas que não a sua, a germânica; em especial, perante a cultura inglesa: "Acerca de um arquiteto ou músico (talvez de um artista em geral) inglês pode-se estar quase seguro de que se trata de um charlatão!", pontificou Wittgenstein (2010a, p.73). Pior ainda: Wittgenstein menosprezava o que não fosse de sua cultura, apesar de abrir exceções a alguns artistas de nacionalidades diversas: 
A educação (aquisição da cultura) restitui a uma pessoa um bem que já lhe pertence. Com ela tal pessoa aprende, por assim dizer, a conhecer a herança paterna. Ao passo que outra pessoa assimila por meio dela formas cuja natureza lhe é estranha. E aí seria melhor se permanecesse inculta ainda que ficando repugnante \& tosca (Wittgenstein 2010a, p.70-71).

O menosprezo de Wittgenstein por uma educação, por uma cultura que não fosse a sua alicerça seu método por exemplos, elaborado para explicar conceitos e proferir julgamentos sempre de seu ponto de vista, de sua cultura, de sua "forma de vida" (Wittgenstein 1999, §23), nunca do ponto de vista do outro, da cultura do outro, da forma de vida do outro. "É como se disséssemos: 'Classifico as obras de arte do seguinte modo: umas admiro, outras desprezo'. Este modo de classificação podia ser interessante" (Wittgenstein 2009, p.33). Sim, este modo de classificação podia ser interessante para alguém que "nunca se via pelos olhos dos outros" e "não tinha outros padrões a não ser os seus" (Pascal 1984, p.47), mas evidentemente não resolve os problemas, nem afasta as dificuldades.

\section{Um meio seguro de permanecer em confusão}

Em conformidade com seu método por exemplos, fundamentado na ideia de que caberia ao filósofo demonstrar uma técnica para chegar à clareza em vez de ensinar doutrinas e desenvolver teorias, o segundo Wittgenstein pretendia resolver os problemas filosóficos pela "serena consideração dos fatos linguísticos" (Wittgenstein 1992b, §447), já que, sob a influência de Hertz, acreditava não apenas que "um modo de expressão inadequado é um meio seguro de permanecer em confusão" (Wittgenstein 1999, §339), mas que "os problemas filosóficos nascem quando a linguagem entra em férias" (1999, §38). Com essa perspectiva, Wittgenstein considerava a filosofia "simplesmente um exercício que prepara para pensar - que nos ajuda a dissipar as confusões" (Bouwsma 2005, p.73). E, "uma vez dissipadas estas, estamos em condições de trabalhar noutra coisa" (Bouwsma 2005, p.73). Em seu otimismo, porém, Wittgenstein parece não ter atinado que as confusões jamais poderão ser totalmente dissipadas porque, como bem disse Russell na introdução ao Tractatus logico-philosophicus, "na prática a linguagem é sempre mais ou menos vaga, de modo a nunca ser completamente preciso o que se afirma" (p.114). O próprio Wittgenstein chama a atenção para a vagueza da linguagem em vários textos de sua segunda filosofia. Na Gramática filosófica, por exemplo, Wittgenstein afirma:

O uso das palavras "proposição", "linguagem" etc. tem a nebulosidade do uso normal de palavras-conceito em nossa linguagem. Pensar que isso os torna inúteis ou mal adaptados ao seu propósito seria como querer dizer "o calor desse fogão não tem utilidade porque você não consegue sentir onde começa e onde acaba" (p.89). 
Já no Livro azul (p.60), Wittgenstein não somente afirma que "são muitas as palavras que não têm um significado preciso" como ressalva: "Mas isto não é um defeito. Pensar o contrário seria como afirmar que a luz do meu candeeiro não é uma luz verdadeira porque não tem um limite bem definido". No §68 das Investigações filosóficas, por sua vez, Wittgenstein aponta a imprecisão de palavras-conceito como "número" e "jogo":

"Bem; então o conceito de número explica-se para você como a soma lógica daqueles conceitos isolados aparentados entre si: número cardinal, número racional, número real, etc., e igualmente o conceito de jogo como soma lógica de conceitos parciais correspondentes." Isto não precisa ser assim. Pois posso dar ao conceito de número limites firmes, isto é, usar a palavra "número" para a designação de um conceito firmemente delimitado, mas posso usá-lo também de tal modo que a extensão do conceito não seja fechada por um limite. E assim empregamos a palavra "jogo". Como o conceito de jogo está fechado? O que é ainda um jogo e o que não o é mais? Você pode indicar os limites? Não. Você pode traçar alguns: pois ainda não foi traçado nenhum. (Mas isto nunca o perturbou, quando você empregou a palavra "jogo".)

Ciente de que "não conhecemos os limites" do que chamamos jogos (Wittgenstein 1999, §69), Wittgenstein se pergunta no §75 das Investigações filosóficas:

O que significa saber o que é um jogo? O que significa saber e não poder dizer o que é? É este saber algum equivalente de uma definição não expressa? De tal modo que se eu a visse expressa poderia reconhecê-la como expressão de meu saber? Não está expresso meu saber, meu conceito de jogo, na explicação que eu pudesse dar? Notadamente no fato de que descrevo exemplos de diferentes tipos de jogos, mostro como se pode construir, por analogia, todas as espécies possíveis de jogos; digo que quase não chamaria mais de jogo a isto ou àquilo; e assim por diante.

Outras pessoas, é claro, poderiam dar explicações muito diversas da de Wittgenstein e descrever exemplos de tipos de jogos que Wittgenstein não conhecia, ou de que não gostava - não sei. $O$ fato a ser sublinhado aqui é que diferentes pessoas poderiam agir diferentemente, já que os conceitos não têm limites fixos. Em outros termos: "Conceitos com limites fixos exigiriam uma uniformidade de comportamento. Mas onde eu estou seguro, um outro está inseguro. E isto é um fato da natureza" (Wittgenstein 1992b, §374). E justamente devido a esse "fato da natureza" certas inquietudes nunca desaparecerão - nem que se imprimam palavras de cabeça para baixo para ressaltar sua imprecisão, como Wittgenstein sugeriu a Basil Reeve quando redigiram um relatório sobre "choque" no Guy's Hospital de Londres (Monk 1995, p.398).

De acordo com Monk (1995, p.396-7), enquanto trabalhava nesse hospital durante a Segunda Guerra, Wittgenstein se interessou pelas pesquisas do dr. R. T. Grant 
ao saber que ele havia adotado uma solução semelhante à de Hertz para dissipar a confusão relativa ao conceito de "choque traumático". Conforme Monk, ao longo do conflito, o dr. Grant atendia pacientes com "choque traumático" em decorrência dos bombardeios alemães e, num memorando sobre o assunto, expressou objeções ao uso desse conceito, propondo "evitar o diagnóstico de 'choque' e substituí-lo por um registro preciso e completo do estado e progresso do paciente paralelamente ao seu tratamento" (Monk 1995, p.397). Dessa forma, assim como Hertz propunha reformular a física newtoniana sem usar "força" como um conceito básico, o dr. Grant propunha uma medicina sem o uso de "choque" como um conceito básico. Tendo concordado com a abordagem do dr. Grant, Wittgenstein sugeriu a Reeve que imprimissem "choque" de cabeça para baixo no relatório que haviam redigido para destacar sua falta de limites fixos. Curiosamente, porém, na Gramática filosófica, escrita certa de 10 anos antes, a imprecisão das palavras "proposição" e "linguagem" não levou Wittgenstein a cogitar eliminá-las ou imprimi-las de cabeça para baixo. Fato mais curioso ainda, Wittgenstein bem observa no Livro azul (p.57):

Os médicos usam nomes de doenças sem nunca decidirem quais os fenômenos que devem ser considerados como critérios e quais como sintomas; e isto não constitui necessariamente uma falta deplorável de clareza. Devem lembrar-se de que não utilizamos geralmente a linguagem de acordo com regras rigorosas.

Assim, "estamos sempre concluindo dos sintomas para as doenças e sabemos que os sintomas mais diferentes podem ser sintomas da mesma coisa" (Wittgenstein 2003, p.286). E os mais diferentes sintomas dos pacientes atendidos pelo dr. Grant podiam ser sintomas da mesma coisa: choque traumático. Afinal, os médicos usam nomes de doenças sem nunca decidirem quais os fenômenos que devem ser considerados como critérios e quais como sintomas; e isto não constitui necessariamente uma falta deplorável de clareza - como não constituiu uma falta deplorável de clareza o diagnóstico de que Wittgenstein estava em "estado de choque" e com ferimentos leves depois de uma explosão na oficina em que ele trabalhava durante a Primeira Guerra Mundial (Monk 1995, p.129). Por isso, tão somente evitar o diagnóstico de "choque" e substituí-lo por um registro preciso e completo do estado e progresso do paciente paralelamente ao seu tratamento não resolveria o problema - assim como não resolveu o problema simplesmente omitir a palavra, como se fez no título do relatório final sobre "choque", "Observações sobre os efeitos gerais de ferimentos no homem", que talvez tenha sido escrito pelo próprio Wittgenstein (Monk 1995, p.402). Mas, independentemente de quem tenha redigido o relatório, o fato é que em sua filosofia Wittgenstein adota uma postura bem diferente dessa de omitir uma palavra ou sugerir imprimi-la de cabeça para baixo a fim de ressaltar sua imprecisão. Isso não significa, porém, que tenha conseguido atingir a clareza completa, dissipando assim 
as confusões, já que a linguagem é inexoravelmente vaga. Para piorar a situação, dado que "o falar da linguagem é uma parte de uma atividade ou de uma forma de vida" (Wittgenstein 1999, §23), diferenças linguísticas e culturais entre as pessoas fazem com que os mesmos jogos de linguagem tenham significados diferentes para elas. Wittgenstein mesmo, apesar de ter vivido por muitos anos na Inglaterra, longe de sua Viena natal, "não conseguia estabelecer uma relação de plena confiança com as pessoas de Cambridge, pois, dadas as diferenças linguísticas e culturais (...), nunca podia ter certeza de estar sendo compreendido" (Monk 1995, p.246). Com isso, "sempre que surgia algum mal-entendido, sua tendência era atribuí-lo a essas diferenças" (Monk 1995, p.246), como o fez certa vez em conversa com Frank Ramsey: "O que uma afirmação parece implicar para mim não é o mesmo que para você", disse-lhe Wittgenstein (Monk 1995, p.246). "Se algum dia você viver entre estrangeiros por certo período de tempo e depender deles haverá de compreender as minhas dificuldades".

Além das dificuldades e mal-entendidos que surgem devido às diferenças linguísticas e culturais entre as pessoas, é importante ressaltar as dificuldades e malentendidos que surgem devido a diferenças históricas. Essas, no entanto, foram descartadas por Wittgenstein como sem importância para suas investigações filosóficas em uma aula no início dos anos 1930 (Wittgenstein 2001, p.31). Apesar disso, pouco tempo mais tarde, já tendo talvez se atentado para o fato de que "o jogo de linguagem muda com o tempo" (Wittgenstein 1998, §256), Wittgenstein observou: "O conceito de 'festa'. Associamo-lo a divertimento; numa outra época pode ter estado ligado ao medo e ao pavor. O que chamamos 'espírito' e 'humor' não existia, sem dúvida, noutras épocas. E ambos estão constantemente a mudar" (Wittgenstein 1992a, p.115). Por mudar com o tempo, o conceito de "festa", como ensina Friedrich Nietzsche na segunda dissertação de sua Genealogia da moral (§6 e §7), numa outra época esteve ligado ao medo e ao pavor, e o que chamamos "espírito" e "humor" não existia. Os conceitos morais, tão caros a Nietzsche, evidentemente também mudam com o tempo e em diferentes formas de vida, já que "cada cultura tem sua própria forma de moral" (Spengler 1973, p.207) e "em povos diversos as avaliações morais são necessariamente diversas" (Nietzsche 2012, §345). Assim, "nenhum dos juízos éticos que afirmam que um certo tipo de ação é bom enquanto meio para obter um certo tipo de efeito poderá ser universalmente verdadeiro, e muitos que poderão ser geralmente verdadeiros num determinado período serão geralmente falsos noutros" (Moore 1999, §16). Atento a isso, Nietzsche ensina, por exemplo, que a humildade como um sentimento bom foi instituída pelos cristãos, não pelos gregos, que também "tinham outro sentimento sobre a inveja que nós" e "diferiam de nossas avaliações da esperança" $(2008, \S 38)$. Essas diferenças comprovam o fato de que "as mesmas palavras podem tomar, por força da mutabilidade da linguagem pelo decorrer do tempo, um outro sentido, expressar um outro pensamento" (Frege 2002, p.37). E esse é um 
meio seguro de permanecer em confusão, como reconheceu o próprio Wittgenstein:

Se encontrássemos uma sentença como "Os assírios conheciam vários jogos" num livro de história, sem mais qualificações, isso nos causaria uma impressão muito curiosa pois não teríamos certeza de que poderíamos oferecer um exemplo que, mesmo toscamente, correspondesse ao significado da palavra "jogo" nesse caso (Wittgenstein 2003, p.88).

Por fim, além das dificuldades e mal-entendidos que surgem devido a diferenças linguísticas, culturais e históricas, devem ser mencionadas as dificuldades e malentendidos que surgem devido a diferenças individuais, das quais o próprio Wittgenstein dá abundantes testemunhos. No início dos anos 1930, por exemplo, Wittgenstein anotou em seu diário: "É estranho quando dois mundos podem viver em dois quartos um sob o outro. Isso acontece quando moro embaixo dos dois estudantes que fazem barulho acima de mim. São realmente dois mundos \& não é possível nenhum entendimento" (Wittgenstein 2010a, p.89). Àquela altura um renomado filósofo com mais de 40 anos e veterano de guerra do esfacelado Império Austro-Húngaro, Wittgenstein não exagerava ao dizer que seu mundo não era o mundo de seus vizinhos estudantes. No entanto, o mundo de Wittgenstein também não era o mundo de seus colegas de farda na Primeira Guerra Mundial, tachados por ele de "um bando de delinquentes (...) sem nenhum entusiasmo por coisa alguma, inacreditavelmente grossos, estúpidos e mal-intencionados" (Monk 1995, p.114-5); pessoas "tão mesquinhas quanto aterradoramente limitadas" (Monk 1995, p.136), o que tornava "quase impossível trabalhar com elas", pois sempre entendiam "tudo errado" (Monk 1995, p.136). Para Wittgenstein, faltava a elas caráter e, portanto, profundidade. Como aos russos com os quais conviveu quando morou por breve período na União Soviética (Monk 1995, p.318), um mundo completamente diferente da Inglaterra e de sua Áustria natal. Mas mesmo na Áustria Wittgenstein encontraria mundos completamente diferentes do seu, nos quais nenhum entendimento seria possível. Quando adolescente, na escola em Linz, na qual só tinha um amigo íntimo e era hostilizado pela maioria dos colegas (Monk 1995, pp.29-30), o filho de industrial multimilionário não se entendia com os demais estudantes, oriundos em sua maioria da classe trabalhadora, os quais definiu como "estrume" (Monk 1995, p.29). Na década de 1920, o professor primário natural de Viena e egresso de Cambridge tampouco se entendeu com os moradores do vilarejo de Hassbach, os quais, segundo ele, não eram humanos, mas "vermes execráveis" (Monk 1995, p.200), assim como, para ele, as pessoas de Puchberg eram "um quarto animal e três quartos seres humanos" e as de Otterthal eram seres "inumanos" (Monk 1995, p.213).

Em circunstâncias mais amenas, diferentemente do que se poderia esperar, Wittgenstein também encontraria mundos completamente diferentes do seu, nos quais nenhum entendimento seria possível. Em meados dos anos 1940, por exemplo, Wittgenstein morou por um tempo na casa de um pastor metodista, o reverendo Wynford 
Morgan. Quando este lhe perguntou se ele acreditava em Deus, Wittgenstein foi taxativo: "Acredito, mas a diferença entre aquilo em que você acredita e aquilo em que eu acredito talvez seja infinita" (Monkk 1995, p.411). Talvez fosse infinita também a diferença entre aquilo em que o pastor Morgan acreditava, aquilo em que Wittgenstein acreditava e aquilo em que Russell acreditava: "O que você chama Deus é bem o que eu chamo infinito" (Monk 1995, p.49), escreveu Russell a Ottoline Morrell em 1911, quando, segundo Monk (1995, p.49), "estava longe de ser o racionalista cáustico e ofensor da fé que ele mais tarde se tornaria". Em vista de diferenças como essas entre as pessoas, não surpreende que Wittgenstein tenha se perguntado: "Como posso eu saber que duas pessoas se referem ao mesmo quando cada uma delas diz acreditar em Deus?" (Wittgenstein 1992a, pp.124-5). Nem surpreende que ele tenha concluído logo adiante: "É a prática que confere às palavras o seu sentido" (Wittgenstein 1992a, p.125). Realmente é a prática que confere às palavras o seu sentido, mas, "em função da ligação incerta das representações com as palavras, para uma pessoa pode haver uma diferença que uma outra não reconheça" (Frege 2009, p.25). E esse, mais do que qualquer outro, é um meio seguro de permanecer em confusão.

A despeito, porém, da "nebulosidade do uso normal de palavras-conceito em nossa linguagem" e das dificuldades e mal-entendidos que surgem devido às diferenças linguísticas, culturais, históricas e individuais entre as pessoas, a meta final de Wittgenstein era substituir confusão não apenas por clareza, mas por clareza completa, como afirmou no já citado $\$ 133$ das Investigações filosóficas. Na verdade, antes mesmo de escrever as Investigações filosóficas, Wittgenstein já havia revelado a integrantes do Círculo de Viena sua aspiração à clareza completa, absoluta, com a qual acreditava que nenhuma disputa entre filósofos poderia surgir:

Se houvesse teses em filosofia, teriam de ser tais que não suscitassem disputas. Teriam de ser expostas de tal maneira que todos dissessem: Ah, sim, isso é evidentemente óbvio. Enquanto houver a possibilidade de existir opiniões divergentes ou disputas sobre uma questão, isso indica que as coisas ainda não foram expressas de modo suficientemente claro. Quando se houver conseguido uma formulação perfeitamente clara - a clareza absoluta —, não poderá haver mais vacilação ou relutância, que se originam da sensação de que algo foi enunciado que nós não sabemos se admitimos ou não. Contudo, se deixarmos a gramática clara a nós mesmos, se procedermos a passos bem curtos de tal maneira que cada passo fique perfeitamente óbvio e natural, nenhuma disputa poderá surgir. A controvérsia sempre surge quando se omitem ou se deixam de expor claramente determinados passos, deixando a impressão de se haver alegado algo que pode ser contestado (McGuinness 1979, p.183 apud Monk 1995, pp.290-1).

No $§ 128$ das Investigações filosóficas, Wittgenstein sintetiza sua posição: "Se se quisesse expor teses em filosofia, nunca se chegaria a uma discussão sobre elas, porque todos estariam de acordo". Assim, para Wittgenstein, não há teses em filosofia e 
opiniões divergentes ou disputas sobre uma questão indicam que as coisas ainda não foram expressas de modo suficientemente claro e que, quando se houver conseguido uma formulação perfeitamente clara — a clareza absoluta —, não poderá haver mais vacilação ou relutância, que para ele se originam da sensação de que algo foi enunciado que nós não sabemos se admitimos ou não. Ao aspirar, porém, à clareza completa, absoluta, Wittgenstein parece não ter se dado conta de que opiniões divergentes ou disputas sobre uma questão não indicam simplesmente que as coisas ainda não foram expressas de modo suficientemente claro. Muito menos parece ter considerado o problema a respeito de quem seria o enunciador que deveria conseguir uma formulação perfeitamente clara - a clareza absoluta; quem seria a pessoa que deveria deixar a gramática clara, procedendo a passos bem curtos de tal maneira que cada passo ficasse perfeitamente óbvio e natural, até o ponto em que nenhuma disputa pudesse surgir. Dado revelador, quando surgiam disputas com o próprio Wittgenstein, ele frequentemente desconsiderava seu interlocutor. Nos encontros do Círculo de Viena, por exemplo, segundo Rudolf Carnap, Wittgenstein "não tolerava exames críticos da parte de outros, pois a intuição lhe viera por um ato de inspiração" (Monk 1995, p.226). O próprio Carnap verificaria na pele essa intolerância, já que, por ter pedido várias vezes a Wittgenstein que esclarecesse sua ideia sobre a possibilidade de falar sobre expressões linguísticas, foi banido de sua presença (Goldestein 2008, p.88). "Se ele (Carnap) não consegue farejar isso", disse Wittgenstein a Herbert Feigl, "não posso ajudá-lo. Ele simplesmente não tem nariz!" (Goldestein 2008, p.89). Quando a admiração de Feigl por Carnap se tornou evidente, ele também foi banido da presença de Wittgenstein (Goldestein 2008, p.89).

Poucos anos depois de ter banido Carnap e Feigl de sua presença, Wittgenstein daria mais uma mostra de ser "um homem totalmente incapaz de levar adiante uma discussão" (Drury 1984, p.103), como o definiu o lógico W. E. Johnson, ao apresentar o Tractatus como tese em Cambridge. Na ocasião, Wittgenstein desprezou os comentários de seus examinadores, Russell e G. E. Moore: "Não se preocupem, eu sei que vocês jamais vão compreender" (Monk 1995, p.249), disse-lhes Wittgenstein. Russell, que teve como um de seus objetivos ao proferir a conferência "As tendências atuais", em 1912, "justificar a atitude científica contra a atitude mística" (Russell 1966, p.14), tendo inclusive afirmado que "a lógica empregada em defesa do misticismo" é "defeituosa como lógica" (Russell 1966, p. 15), realmente jamais "compreendeu" a mistura de lógica e misticismo no Tractatus. Além disso, por considerar a religião "uma doença nascida do medo" e "uma fonte de indizível sofrimento para a raça humana" (Russell 1972, p.20), Russell jamais "compreendeu" também a religiosidade de Wittgenstein, que se tornou cristão durante a Primeira Guerra Mundial, sob a influência da leitura do Evangelho explicado, de Tolstoi (Monk 1995, p.115). Politicamente, Russell tampouco "compreendeu" a simpatia de Wittgenstein pelo comunismo (Monk 1995, p.309), já que desprezava o regime soviético (cf. Russell 1967, II, p.135ss). 
Nem "compreendeu" a objeção de Wittgenstein ao sufrágio universal (Monk 1995, p.79), causa que defendeu até mesmo se candidatando ao Parlamento Britânico pelo Partido do Sufrágio das Mulheres em 1907 (Russell 1967, I, pp.208-11). Mas muito mais importante: Russell nunca "compreendeu" também a segunda filosofia de Wittgenstein, cujas doutrinas positivas lhe pareciam triviais e cujas doutrinas negativas lhe pareciam infundadas (Russell 1960, p.193).

Tendo em vista todas essas controvérsias entre Russell e seu ex-aluno Wittgenstein, que obviamente não nasceram quando a linguagem entrou em férias, seria ingênuo acreditar que as disputas entre eles deixariam de surgir se eles deixassem a gramática clara a si mesmos, se procedessem a passos bem curtos de tal maneira que cada passo ficasse perfeitamente óbvio e natural. Afinal, é notório que as controvérsias entre Russell e Wittgenstein vinham do fato de que suas opiniões e pontos de vista eram divergentes, o que os levou a disputas logo nos primeiros meses de convivência (Monk 1995, pp.61-2) e posteriormente ao fim da amizade entre eles: "Nossas rixas não decorrem apenas de motivos externos como irritabilidade ou exaustão, mas pelo menos da minha parte - têm raízes muito profundas", escreveu Wittgenstein a Russell em 1914 (Russell 1960, p.101). "(...) nossos ideais não poderiam divergir mais. E é por isso que não conseguimos e jamais conseguiremos conversar sobre qualquer coisa que envolva nossos juízos de valor sem nos tornarmos hipócritas ou começarmos a brigar." E é por isso também que seria definitivamente ingênuo acreditar que as disputas entre Russell e Wittgenstein sobre as mais diversas questões deixariam de surgir se eles deixassem a gramática clara a si mesmos, se procedessem a passos bem curtos de tal maneira que cada passo ficasse perfeitamente óbvio e natural; se, em suma, houvessem conseguido uma formulação perfeitamente clara - a clareza absoluta.

\section{As disputas de Wittgenstein sobre os fundamentos da ma- temática}

Igualmente ingênuo seria acreditar que as disputas entre Wittgenstein e os matemáticos sobre os fundamentos da matemática deixariam de surgir se eles deixassem a gramática clara a si mesmos, se conseguissem uma formulação perfeitamente clara - a clareza absoluta. Em particular, as disputas de Wittgenstein com os matemáticos Kurt Gödel e Alan Turing, cujo primeiro grande episódio se deu no famoso congresso sobre a "Epistemologia das ciências exatas" realizado em 1930 na cidade de Königsberg. Nesse evento, expoentes das principais escolas da filosofia da matemática defenderam seus respectivos pontos de vista. O matemático holandês Arend Heyting representou os intuicionistas; o matemático húngaro John von Neumann, os formalistas; Rudolf Carnap, os logicistas. Já Friedrich Waismann, outro integrante 
do Círculo de Viena, falou pelo recluso Wittgenstein, resumindo suas novas ideias sobre a natureza da matemática. Um breve comunicado, porém, do jovem lógico e matemático Kurt Gödel apresentando seu famoso teorema da incompletude acabaria por superar em importância as demais palestras. Mais tarde, Gödel publicaria ainda um segundo teorema, como desdobramento do primeiro. Com seus dois teoremas da incompletude, Gödel provou que em qualquer sistema formal consistente (isto é, sem que as regras do sistema gerem contradições) haverá sempre uma sentença cuja veracidade ou falsidade não pode ser provada e que a consistência de um sistema formal de aritmética não pode ser provada de dentro do próprio sistema. Dessa forma, Gödel demoliu o projeto do matemático formalista David Hilbert de fornecer uma prova formal finitária da consistência dos axiomas da aritmética de dentro do próprio sistema aritmético. Além disso, provou que a matemática não pode ser reduzida à lógica, como acreditavam logicistas como Gottlob Frege e Russell. "Se Wittgenstein aceitou ou não esta interpretação dos resultados de Gödel é uma questão em aberto", observa Monk (1995, p.270). "Seus comentários sobre o teorema de Gödel (veja Observações sobre os fundamentos da matemática, apêndice da parte I) parecem à primeira vista, para alguém treinado em lógica matemática, espantosamente primitivos." À segunda, terceira, quarta vista, os comentários de Wittgenstein sobre o teorema de Gödel se confirmam espantosamente primitivos, a ponto de "quase todos (os seus analistas) os terem considerado um constrangimento para o trabalho de um grande filósofo" (Dawson Jr. 1988, pp.88-9). Além do mais, não é uma questão em aberto se Wittgenstein aceitou ou não esta interpretação dos resultados de Gödel (veja Observações sobre os fundamentos da matemática, VII, §19). Nessa seção do livro, Wittgenstein afirma:

Minha tarefa não é atacar de dentro a lógica de Russell, mas de fora.

Ou seja: não atacá-la matematicamente — então faria matemática —, mas sua posição, seu ofício.

Minha tarefa não é falar sobre o teorema de Gödel, por exemplo, mas evitar fazê-lo.

Apesar da afirmação de Wittgenstein, a qual "tende a irritar os matemáticos" (Goldestein 2008, p.161), de que sua tarefa não era falar sobre o teorema de Gödel, mas evitar fazê-lo, ele "retorna, repetidamente, em suas Observações sobre os fundamentos da matemática, ao teorema da incompletude de Gödel (...), tentando mostrar que seu significado está em conflito com sua intenção, que ele não pode significar o que pretende significar" (Goldestein 2008, p.161). Mais: igualmente irritando os matemáticos, Wittgenstein tenta desqualificar a prova de Gödel, dizendo se tratar de um mero resultado de "truques lógicos" (Wittgenstein 1987, I, apêndice III, §19), já que para ele a matemática "não pode ser incompleta, assim como não pode haver um sentido incompleto" (Wittgenstein 2005a, p.156). "Meu propósito é mudar a atitude 
frente à contradição e frente à prova de consistência", escreveu Wittgenstein nas $O b$ servações sobre os fundamentos da matemática (III, §82). Em conversa de dezembro de 1930 com Waismann e Moritz Schlick sobre o assunto, Wittgenstein detalhou sua posição:

Estive lendo uma obra de Hilbert sobre a consistência. Parece-me que toda essa questão recebeu uma formulação errônea. Gostaria de perguntar: A matemática pode ser inconsistente? Gostaria de perguntar a essas pessoas: Ei, o que vocês estão querendo? Acreditam mesmo que existam contradições ocultas na matemática?

(...) se surgem inconsistências entre as regras do jogo da matemática, a coisa mais fácil do mundo seria remediá-las. Tudo o que temos de fazer é uma nova estipulação para abranger o caso em que as regras estão em conflito - e a questão está resolvida (Wittgenstein 2005a, pp.265-6).

Assim, para Wittgenstein, "o que Hilbert faz é matemática, não metamatemática. É um outro cálculo, exatamente como qualquer outro" (Wittgenstein 2005a, p.266). Ou seja, "enquanto pudermos usar os símbolos matemáticos corretamente - enquanto pudermos aplicar as regras —, nenhuma 'teoria' da matemática se faz necessária", resume Monk (1995, p.278) a concepção wittgensteiniana da matemática. "Uma justificação definitiva e fundamental dessas regras não é possível nem desejável. Isso significa que todo o debate sobre os 'fundamentos' da matemática parte de um equívoco." Considerando-se esse ponto de vista,

não surpreende que Wittgenstein descartasse o resultado de Gödel com uma descrição depreciadora como 'logische Kunststücken', truques lógicos, claramente destituídos da importância metamatemática atribuída por Gödel e outros matemáticos. A prova de Gödel, a própria possibilidade de uma prova daquele tipo, é proibida por motivo dos objetivos wittgensteinianos (...). Ele foi inflexível sobre a impossibilidade de falar sobre uma linguagem formal como a prova de Gödel fala (Goldestein 2008, p.160).

Pior: "Ele foi $(\ldots)$ inflexível ao negar que resultados matemáticos, sendo os resultados de mera sintaxe, pudessem ter consequências amplas e interessantes fora da matemática. (...) Ele foi, em suma, inflexível ao negar a possibilidade de uma prova como a de Gödel" (Goldestein 2008, pp.160-1). O próprio Gödel, por sua vez, ao tomar conhecimento dos espantosamente primitivos comentários de Wittgenstein sobre sua prova, limitou-se a afirmar que se tratava de "uma interpretação errônea, totalmente trivial e desinteressante" (Goldestein 2008, p.100; Dawson Jr. 1988, p.89). Em todo caso, a fim de compreender a atitude de Wittgenstein em relação à prova de Gödel, é necessário ter em vista que seu objetivo na verdade era descartar toda a lógica matemática em seu "ataque quixotesco" à matemática pura, como o denominou Monk (1995, p.297). Exatamente com esse intuito, Wittgenstein depreciou 
vários aspectos da discussão sobre os fundamentos da matemática em seu curso sobre o tema ministrado na Universidade de Cambridge em 1939. Inclusive o paradoxo de Russell: ${ }^{5}$

Tomemos a contradição de Russell. Existem conceitos que chamamos predicados — "homem", "cadeira" e "lobo" são predicados, mas "Jack" e "John" não. Alguns predicados aplicam-se a si mesmos e outros não. Por exemplo, "cadeira" não é uma cadeira, "lobo" não é um lobo, mas "predicado" é um predicado. Vocês podem achar isso uma bobagem. E em certo sentido é mesmo (Wittgenstein 1989, p.222 apud Monk 1995, p.372).

Na opinião de Monk (1995, p.372), essa "falta de sofisticação" de Wittgenstein ao examinar o paradoxo de Russell — "do ponto de vista matemático, (...) extraordinariamente primitiva" - tinha "uma finalidade propagandística": "O uso de uma linguagem corriqueira e cotidiana para discutir problemas de lógica matemática e, de resto, descartar como bobagem" o modo como esses problemas foram apresentados serve de antídoto contra a seriedade e o zelo com que foram discutidos por aqueles que se deixaram seduzir pelo seu 'fascínio' (entre os quais se inclui, por exemplo, o próprio Wittgenstein em 1911)". Os matemáticos, porém, jamais levaram a sério esse "antídoto" de Wittgenstein. A começar por um dos ouvintes desse curso, o matemático Alan Turing, que coincidentemente naquele mesmo ano havia dado um curso em Cambridge intitulado "Fundamentos da matemática" no qual os alunos eram apresentados à técnica de demonstrar teoremas matemáticos a partir de um sistema rigorosamente axiomático de lógica — ou seja, a fonte do fascínio matemático que Wittgenstein tentou descartar como "bobagem". Dadas as divergências de opinião entre Wittgenstein e Turing a respeito da matemática, suas disputas sobre o tema eram inevitáveis.

Conforme Monk (1995, p.373), Wittgenstein provavelmente acreditava que, se conseguisse convencer Turing a ver a matemática sob sua ótica, poderia convencer qualquer um. No entanto, Wittgenstein não conseguiu convencer Turing, que, indagado se compreendia o que Wittgenstein estava dizendo, teria respondido: "Compreendo, mas não concordo que se trate apenas de uma questão de dar novos significados a palavras" (1995, p.373). Wittgenstein, por sua vez, "de maneira um tanto bizarra" — criticou-o Monk (1995, p.373) —, teria retrucado: "Turing não faz objeção a nada do que eu digo. Ele concorda com cada palavra. Mas objeta à ideia que acredita estar subjacente. Pensa que estamos solapando a matemática, introduzindo o bolchevismo na matemática. Absolutamente não" (1995, p.374). Quanto a essas disputas entre Wittgenstein e Turing, Monk é incisivo:

Do modo como Wittgenstein concebia seu método filosófico, era importante que não pudesse haver discordância de opinião entre ele e Turing. Se na sua filosofia ele não estava propondo teses, como poderia haver algo do que 
discordar? Quando Turing usou certa vez a expressão "Entendo aonde você quer chegar", Wittgenstein reagiu vigorosamente: "Não quero chegar a parte alguma". Se Turing sentia-se inclinado a objetar ao que Wittgenstein estava dizendo, só podia ser porque ele usava as palavras de uma maneira diferente - só podia ser uma questão dos significados das palavras. Ou melhor, só podia ser uma questão de Turing não entender o uso que Wittgenstein fazia de certas palavras (1995, p.374).

Ou melhor ainda, só podia ser uma questão de Wittgenstein - que acreditava estar "persuadindo as pessoas a mudar seu estilo de pensar" (Monk 1995, p.361) — não entender que havia de fato discordância de opinião entre ele e Turing. Sintomaticamente, de maneira ainda mais bizarra, Wittgenstein disse aos alunos: “(...) obviamente o aspecto essencial da questão (sobre os fundamentos da matemática) é que não devo ter uma opinião" (Wittgenstein 1989, p.55). Mas obviamente Wittgenstein tinha uma opinião sobre a questão dos fundamentos da matemática. $\mathrm{Na}$ verdade, Wittgenstein "claramente tinha opiniões bastante fortes (sobre a questão dos fundamentos da matemática) — e opiniões que, ademais, divergiam da maneira como a maioria dos matemáticos profissionais concebiam a disciplina" (Monk 1995, p.374). Para complicar a situação de Wittgenstein,

se estiverem em conformidade com sua metodologia da "não opinião", suas próprias observações podem não constituir uma contribuição genuína ao debate filosófico. Por outro lado, na hipótese de não estarem em conformidade com ela, sua prática desmente seus declarados pontos de vista metodológicos - ele estaria propondo a tese não óbvia de que não há teses filosóficas não óbvias (Glock 1998, p.167).

Em vista dessas dificuldades, não admira que alguns wittgensteinianos, como Anthony Kenny (2006, p.xix), achem incompatíveis a explicação da filosofia que Wittgenstein faz e sua atividade filosófica apresentada nas Investigações filosóficas. "Nós somos forçados no fim a fazer uma escolha entre aceitar sua teoria e seguir sua prática”, sentencia Kenny (2006, p.xix). ${ }^{6}$ De qualquer maneira, o fato é que, por acreditar que objeções a suas explicações só podiam surgir por incompreensão, a clareza à qual Wittgenstein aspirava era na verdade uma clareza completa, absoluta, com a qual acreditava que nenhuma disputa poderia surgir. Se surgisse, na opinião de Wittgenstein, só podia ser porque se usavam as palavras de uma maneira diferente — só podia ser uma questão dos significados das palavras. Em relação a isso, Monk (1995, p.374) é novamente preciso:

(...) Turing afirmava ser possível haver experimentos em matemática, isto é, ser possível empreender uma investigação matemática no mesmo espírito com que se realizam experimentos de física: "Não sabemos no que isso vai dar, mas vamos tentar..." Para Wittgenstein, isso era absolutamente impossível; toda e qualquer analogia entre matemática e física era equivocada, 
constituindo mesmo uma das fontes mais importantes das confusões que estava tentando retificar. Porém, como tornar isso claro sem opor ao ponto de vista de Turing um ponto de vista próprio? Ele precisava: (a) fazer com que Turing admitisse que ambos estavam usando a palavra "experimento" no mesmo sentido; e (b) fazê-lo ver que, neste sentido, os matemáticos não fazem experimentos.

Wittgenstein, no entanto, não fez com que Turing admitisse que ambos estavam usando a palavra "experimento" no mesmo sentido nem o fez ver que, neste sentido, os matemáticos não fazem experimentos. Incapaz de efetivamente persuadir Turing, que não poderia ser pura e simplesmente banido como Carnap e Feigl, Wittgenstein mais uma vez atribuiu a disputa a uma questão dos significados das palavras, acreditando que, se se expressasse com clareza, o problema desapareceria completamente:

Turing acha que ele e eu estamos usando a palavra "experimento" de duas maneiras diferentes. Mas quero mostrar-lhe que não. Ou seja, acho que se me expressasse com clareza, ele desistiria de afirmar que na matemática se fazem experimentos. Se eu conseguisse dispor na ordem apropriada certos fatos bem conhecidos, ficaria claro que Turing e eu não estamos usando a palavra "experimento" de maneira diferente.

Alguém poderia perguntar: "Como é possível haver um mal-entendido tão difícil de corrigir?".

Talvez se explique em parte por uma diferença de formação cultural (Monk 1995, p.374).

Como bem observou Monk (1995, p.374), para Wittgenstein, esse mal-entendido tão difícil de corrigir "não se explicava por talvez existir uma diferença real de opinião entre ambos". Para Wittgenstein, claro, só podia ser uma questão dos significados das palavras. Por esse motivo, Wittgenstein tampouco reconheceu que sua disputa com Turing sobre a preocupação dos matemáticos em evitar que haja uma contradição em um sistema se explicava por talvez existir uma diferença real de opinião entre ambos. Ao tratar dessa questão, Wittgenstein abordou o paradoxo do mentiroso descartandoo como bobagem, o que gerou mais uma discussão com Turing:

É muito estranho que (o paradoxo do mentiroso) possa ter constituído um enigma para alguém - muito mais extraordinário do que acreditar que esse gênero de coisa possa preocupar os seres humanos. Pois a coisa funciona assim: se um homem disser "Estou mentindo", dizemos que segue que ele não está mentindo, do que se segue que ele está mentindo e assim por diante. Bem, e daí? Podemos levar isso adiante a perder de vista. Por que não? Não tem a mínima importância (Monk 1995, p.375).

"Em geral usamos uma contradição como critério para discernir algo errado", disse-lhe Turing. "Neste caso, porém, não encontramos nada que tenha sido feito errado." "Claro", rebateu Wittgenstein, enunciando algo que Turing não admitiria, "pois 
nada foi feito errado. Alguém poderia dizer: 'Isso só pode ser explicado por uma teoria dos tipos'. Mas o que há que precise ser explicado?" (Monk 1995, p.375). Turing, então, explicou não só por que o paradoxo era enigmático, mas também por que era importante. Os danos causados por um sistema que contenha uma contradição, argumentou, "podem não aparecer até que haja alguma aplicação - quando então uma ponte poderá desabar ou coisa parecida" (Monk 1995, p.375). Assim, "Turing, comprometido com lógica matemática e sabendo do emprego de Gödel de paradoxos tradicionais como o do mentiroso, ${ }^{7}$ tinha a forte impressão de que o paradoxo do mentiroso - de que os paradoxos e contradições em geral - importa sim, e que às vezes indica o caminho para verdades quase necessariamente surpreendentes" (Goldestein 2008, p.166). Wittgenstein, no entanto, foi inflexível sobre a irrelevância das contradições e dos paradoxos e consequentemente a discussão com Turing continuou na aula seguinte:

Turing: Você não pode aplicar um cálculo com confiança se não tiver certeza que ele não apresenta contradições latentes.

Wittgenstein: Parece-me haver um enorme equívoco aqui. Pois o seu cálculo produz certos resultados e você quer que a ponte não caia. Eu digo que as coisas só podem dar errado de duas maneiras: ou a ponte desaba ou você cometeu algum erro em seus cálculos - por exemplo, multiplicou errado. Mas você parece acreditar que pode haver uma terceira maneira: o cálculo estar errado.

Turing: O que eu objeto é que a ponte não desabe.

Wittgenstein: Mas como você sabe que ela irá desabar? Não é uma questão de física? Pode acontecer de alguém jogar dados para calcular uma ponte que jamais desabará.

Turing: Se for adotado o simbolismo de Frege e ensinar-se uma pessoa a técnica de multiplicar com ele, então, usando o paradoxo de Russell, essa pessoa pode efetuar uma multiplicação errada.

Wittgenstein: Isso só poderá acontecer se ela efetuar algo que não podemos chamar de multiplicação. Seguindo uma regra de multiplicação, quando essa pessoa chega a determinado ponto, ela poderá prosseguir de duas maneiras, uma das quais a levará a um caminho totalmente errado (Monk 1995, pp.375-6).

Pouco depois dessa discussão, Turing desistiu de assistir às aulas de Wittgenstein, "convencido, por certo, que se Wittgenstein não admitia que uma contradição é uma deficiência fatal em um sistema matemático, não poderia haver terreno comum entre eles" (Monk 1995, p.376). ${ }^{8}$ Wittgenstein, no entanto, ao que parece, nem assim reconheceu que sua disputa com Turing sobre a preocupação dos matemáticos em evitar que haja uma contradição em um sistema se explicava por talvez existir uma 
diferença real de opinião entre ambos. Para Wittgenstein, indiscutivelmente, só podia ser uma questão dos significados das palavras. ${ }^{9}$

\section{Considerações finais}

Sem ter persuadido Gödel, Turing ou qualquer outro matemático de expressão a mudar seu estilo de pensar, Wittgenstein acabaria abandonando sua filosofia da matemática em 1944. Nesse ano, conforme Monk (1995, p.414), John Wisdom escreveu uma breve nota a respeito de Wittgenstein para incluir em um dicionário biográfico e, antes de publicá-la, pediu-lhe que a comentasse. Wittgenstein fez apenas uma modificação, acrescentando uma última sentença ao texto: "A principal contribuição de Wittgenstein foi na filosofia da matemática". No entanto, ainda de acordo com Monk, dois ou três meses depois, quando Rush Rhees lhe perguntou por seu trabalho em matemática, Wittgenstein lhe respondeu "com um gesto de mão": "Ah, alguém mais pode fazer isso". Apesar da relevância desse episódio para a avaliação do legado de Wittgenstein, a maioria absoluta dos comentadores de sua obra negligencia que ele tenha abandonado aquela que ele considerava sua principal contribuição filosófica. Inclusive aqueles que analisam a influência de Hertz em seu pensamento, de modo geral, e em sua filosofia da matemática, em particular. Um desses pesquisadores, Peter Kjaergaard afirma no artigo "Hertz and Wittgenstein's philosophy of science" que Hertz "teve um papel decisivo no uso de Wittgenstein de um método filosófico único" (p.121) e que Wittgenstein "aplicou esse método com sucesso em problemas críticos de lógica e matemática ao longo de sua vida" (p.121). Como exemplo desses problemas, Kjaergaard cita paradoxos lógicos e questões relativas aos fundamentos da matemática, que eram vistos por Wittgenstein como "pseudoproblemas que requeriam clareza, em vez de solução" (p.121). Mais especificamente, Kjaergaard argumenta que "a resposta controvertida de Wittgenstein a David Hilbert e Kurt Gödel foi profundamente influenciada por Hertz e só pode ser entendida completamente quando vista nesse contexto" (p.121). Até que ponto a resposta de Wittgenstein a Hilbert e Gödel foi influenciada por Hertz é mais uma questão interessante que será deixada de lado neste trabalho. Tendo em vista, porém, as disputas de Wittgenstein com Gödel e Turing sobre os fundamentos da matemática, bem como o fato de Wittgenstein ter abandonado aquela que ele considerava sua principal contribuição filosófica, é difícil concordar com a afirmação (não comprovada) de Kjaergaard de que Wittgenstein aplicou seu método com sucesso em problemas críticos de lógica e matemática. $\mathrm{Na}$ verdade, é difícil acreditar que Wittgenstein tenha aplicado seu método com sucesso em problemas críticos de qualquer natureza. Especialmente levando-se em conta que, anos depois de ter proclamado que o nimbo da filosofia havia se perdido, o próprio Wittgenstein admitiu a Rhees: "Você sabe que eu disse que eu posso parar de fazer 
filosofia quando eu quero. Isto é uma mentira. Eu não posso" (Rhees 1984, p.219, n.7).

\section{Referências}

Barker, P. 1980. Hertz and Wittgenstein. Studies in the History and Philosophy of Science 11: 243-56.

Bouwsma, O. K. 2005. Conversas com Wittgenstein. Tradução de Miguel S. Pereira. Lisboa: Relógio D’Àgua Editores.

Dawson Jr., J. W. 1988. The reception of Gödel's incompleteness theorems. In: S. Shanker (ed.) Gödel's theorem in focus, pp.74-95. Londres; Nova York: Croom Helm.

Drury, M. O'C. 1984. Conversations with Wittgenstein. In: R. Rhees (ed.) Recollections of Wittgenstein: Hermine Wittgenstein; Fania Pascal; F. R. Leavis; John King; M. O'c. Drury, pp.97-171. Oxford: Oxford University Press.

Frege, G. 2002. Investigações lógicas. Tradução de Paulo Alcoforado. Porto Alegre: EDIPUCRS.

- 2009. Sobre o sentido e a referência. In: Lógica e filosofia da linguagem, pp.129-58. $2^{a}$ ed. Tradução de Paulo Alcoforado. São Paulo: Edusp.

Glock, H.-J. 1998. Dicionário Wittgenstein. Tradução de Helena Martins. Rio de Janeiro: Jorge Zahar.

Goldestein, R. 2008. Incompletude: a prova e o paradoxo de Kurt Gödel. Tradução de Ivo Korytowski. São Paulo: Companhia das Letras.

Griffin, J. 1964. Wittgenstein's logical atomism. Oxford: Oxford University Press.

Hacker, P. M. S. 1996. Wittgenstein's place in twentieth-century analytic philosophy. Oxford: Blackwell Publishers.

Heidegger, M. 2006. Ser e tempo. $6^{a}$ ed. Tradução de Márcia Sá Cavalcante Schuback. Petrópolis: Editora Vozes; Bragança Paulista: Editora Universitária São Francisco.

—. 2009. Introdução à filosofia. Tradução de Marco Antonio Casanova. São Paulo: Martins Fontes.

Hertz, H. 1984. Die Prinzipien der Mechanik in neuem Zusammenhange dargestellt. Leipzig: Geest and Portig.

Hintikka, J. 2000. On Gödel. Belmont: Wadsworth/Thomson Learning.

Jammer, M. 2011. Conceitos de força: estudo sobre os fundamentos da dinâmica. Tradução de Vera Ribeiro. Rio de Janeiro: Contraponto: Editora PUC Rio.

Janik, A. 1994. How did Hertz influence Wittgenstein's philosophical development? Grazer Philosophical Studies 49: 19-47.

Janik, A.; Toulmin, S. 1991. A Viena de Wittgenstein. Tradução de Álvaro Cabral. Rio de Janeiro: Editora Campus.

Kant, I. 2013 [1781/1787]. Crítica da razão pura. $2^{a}$ ed. Tradução de Fernando Costa Mattos. Petrópolis: Editora Vozes; Bragança Paulista: Editora Universitária São Francisco.

Kenny, A. 2006. Wittgenstein. Oxford: Blackwell Publishing.

Kjaergaard, P. C. 2002. Hertz and Wittgenstein's philosophy of science. Journal for General Philosophy of Science 33: 121-49.

Kuusela, O.; McGinn, M. 2014a. Editors' introduction. In: O. Kuusela; M. McGinn (ed.) The Oxford Handbook of Wittgenstein, pp.3-12. Oxford: Oxford University Press. 
Kuusela, O.; McGinn, M. (ed.) 2014b. The Oxford Handbook of Wittgenstein. Oxford: Oxford University Press.

Malcolm, N. 1990. Ludwig Wittgenstein: esbozo biografico de G. H. von Wright. Tradução espanhola de Mario Garcia Aldonate. Madri: Biblioteca Mondadori.

McGuinness, B. F. (ed.) 1979. Ludwig Wittgenstein and the Vienna Circle: conversations recorded by Friedrich Waismann. Oxford: Blackwell.

Monk, R. 1990. Ludwig Wittgenstein: the duty of genius. Nova York: Penguin.

- 1995. Wittgenstein: o dever do gênio. Tradução de Carlos Afonso Malferrari São Paulo: Companhia das Letras.

Moore, G. E. 1999. Principia ethica. Tradução de Maria Manuela Rocheta Santos e Isabel Pedro dos Santos. Lisboa: Fundação Calouste Gulbenkian.

Moreno, A. R. (org.) 2013. Wittgenstein e a epistemologia. Campinas: Unicamp/CLE.

Nagel, E.; Newman, J. R. 2001. A prova de Gödel. Tradução de Gita K. Guinsburg. São Paulo: Perspectiva.

Nietzsche, F. 2008. Aurora: reflexões sobre os preconceitos morais. Tradução de Mário D. Ferreira Santos. Petrópolis: Editora Vozes.

—. 2009. Genealogia da moral: uma polêmica. Tradução de Paulo César de Souza. São Paulo: Companhia das Letras.

— 2012. A gaia ciência. Tradução de Paulo César de Souza. São Paulo: Companhia das Letras.

Pascal, F. 1984. Wittgenstein: a personal memoir. In: R. Rhees (ed.) Recollections of Wittgenstein: Hermine Wittgenstein; Fania Pascal; Frank R. Leavis; John King; Maurice O'C. Drury, pp.12-49. Oxford: Oxford University Press.

Pears, D. F. 1973. As ideias de Wittgenstein. Tradução de Octanny Silveira de Mota e Leonidas Hegenberg. São Paulo: Cultrix: Ed. Universidade de São Paulo.

Preston, J. 2008. Hertz, Wittgenstein and philosophical method. Philosophical Investigations 31(1): 48-67.

Rhees, R. (ed.) 1984. Recollections of Wittgenstein: Hermine Wittgenstein; Fania Pascal; F. R. Leavis; John King; M. O'c. Drury. Oxford: Oxford University Press.

Russell, B. 1960. Meu pensamento filosófico. Tradução de Brenno Silveira. São Paulo: Companhia Editora Nacional.

- 1966. Nosso conhecimento do mundo exterior: estabelecimento de um campo para estudos sobre o método científico em filosofia. Tradução de R. Haddock Lobo. São Paulo: Companhia Editora Nacional e Editora da Universidade de São Paulo.

—. 1967. Autobiografia de Bertrand Russell. Tradução de Brenno Silveira. Rio de Janeiro: Civilização Brasileira, $3 \mathrm{v}$.

- 1972. Porque não sou cristão e outros ensaios sobre religião e assuntos correlatos. $2^{a}$. ed. Tradução de Brenno Silveira. São Paulo: Exposição do Livro.

- 2010. Introdução ao Tractatus logico-philosophicus. In: L. Wittgenstein, Tractatus logico-philosophicus, pp.113-28. São Paulo: Edusp.

Schulte, J. 1992. Wittgenstein: an introduction. Nova York: State University of New York Press. Shanker, Stuart (ed.) 1988. Gödel's theorem in focus. Londres; Nova York: Croom Helm.

Silva, G. A. F. 2018. Observações sobre a filosofia da matemática de Ludwig Wittgenstein. Griot: Revista de Filosofia 17(1): 97-113.

Simões, E. 2012. Hertz, Wittgenstein e a representação do mundo. Curitiba: CRV. 
2013. Darstellungen nos Princípios da mecânica e no Tractatus: a representação dos objetos e a figuração do mundo em Hertz e em Wittgenstein. In: A. R. Moreno (org.) Wittgenstein e a epistemologia, pp.223-45. Campinas: Unicamp/CLE.

Smith, P. 2007. An introduction to Gödel's theorems. Cambridge, UK; Nova York: Cambridge University Press.

Snowdon, P. 2014. Private experience and sense data. In: O. Kuusela; M. McGinn (ed.) The Oxford Handbook of Wittgenstein, pp.402-28. Oxford: Oxford University Press.

Spengler, O. 1973. A decadência do Ocidente: esboço de uma morfologia da história universal. $2^{a}$. ed. Tradução de Herbert Caro. Rio de Janeiro: Zahar Editores.

Wittgenstein, L. 1987. Observaciones sobre los fundamentos de la matemática. Tradução espanhola de Isidoro Reguera. Madri: Alianza Editorial.

- 1989. Wittgenstein's lectures on the foundations of mathematics. Cambridge, 1939: from the notes of R. G. Bosanquet, Norman Malcolm, Rush Rhees, and Yorick Smythies. Diamond, Cora (ed.). Chicago e Londres: The University of Chicago Press.

—. 1992a. Cultura e valor. Tradução de Jorge Mendes. Lisboa: Edições 70.

- 1992b. Fichas (Zettel). Tradução de Ana Berhan da Costa. Lisboa: Edições 70.

— 1998. Da certeza. Tradução de Maria Elisa Costa. Lisboa: Edições 70. 1999. Investigações filosóficas. Tradução de José Carlos Bruni. São Paulo: Abril Cultural. (Coleção: Os pensadores).

- 2001. Wittgenstein's lectures: Cambridge, 1932-1935. Ambrose, Alice; Macdonald, Margaret (ed.). Amherst, N.Y.: Prometheus Books.

- 2003. Gramática filosófica. Tradução de Luís Carlos Borges. São Paulo: Loyola.

- 2004. Cadernos: 1914-1916. Tradução de João Tiago Proença. Lisboa: Edições 70.

—. 2005a. Observações filosóficas. Tradução de Adail Sobral e Maria Stela Gonçalves. São Paulo: Loyola.

- 2005b. The Big Typescript: TS 213. Oxford: Blackwell Publishing.

- 2008. O livro azul. Tradução de Jorge Mendes. Lisboa: Edições 70.

. 2009. Aulas e conversas sobre estética, psicologia e fé religiosa. Tradução de Miguel Tamen. Lisboa: Cotovia.

—. 2010a. Movimentos de pensamento: diários de 1930-32/1936-37. Tradução de Edgar da Rocha Marques. São Paulo: Martins Fontes.

— 2010b. Tractatus logico-philosophicus. Tradução de Luiz Henrique Lopes dos Santos. São Paulo: Edusp.

\section{Notas}

${ }^{1}$ As traduções das citações de obras não publicadas em português foram feitas pelo autor.

2 "In my way of doing philosophy, its whole aim is to give an expression such a form that certain disquietudes disappear (Hertz)" (Monk 1990, p.446). "As I do philosophy, its entire task is to shape expression in such a way that certain worries disappear. ((Hertz.))" (Wittgenstein 2005b, p.310).

${ }^{3}$ Apesar de ter tido acesso ao texto original, neste caso como em outros ao longo do artigo optei por me valer da citação feita por Monk (1995) não apenas por se tratar de trecho já traduzido para o português, mas também para aproveitar os comentários desse autor. 
${ }^{4}$ Para uma apresentação e análise do chamado programa de Hilbert, do logicismo de Frege e Russell e dos teoremas de Gödel, ver, por exemplo, Goldestein (2008), Hintikka (2000), Nagel e Newman (2001), Shanker (1988) e Smith (2007).

5 “O paradoxo de Russell", resume Goldestein (2008, pp.76-7), "envolve o conjunto de todos os conjuntos que não são elementos de si mesmos. Conjuntos são objetos abstratos que contêm elementos, e alguns conjuntos podem ser elementos de si mesmos. Por exemplo, o conjunto de todos os objetos abstratos é elemento de si mesmo, já que é um objeto abstrato. Alguns conjuntos (a maioria) não são elementos de si mesmos. Por exemplo, o conjunto de todos os matemáticos não é um matemático — é um objeto abstrato — de modo que não é elemento de si mesmo. Agora formamos o conceito do conjunto de todos os conjuntos que não são elementos de si mesmos e perguntamos: ele é elemento de si mesmo? Ou ele é, ou não é, assim como a sentença problemática do paradoxo do mentiroso é, ou não é verdadeira. Mas, se o conjunto de todos os conjuntos que não são elementos de si mesmos é um elemento de si mesmo, então ele não é elemento de si mesmo, já que contém apenas conjuntos que não são elementos de si mesmos. E, se não for elemento de si mesmo, então é um elemento de si mesmo, já que contém todos os conjuntos que não são elementos de si mesmos. Assim, ele é membro de si mesmo se e somente se não é elemento de si mesmo. Nada bom." Para uma discussão das implicações do paradoxo de Russell, ver, por exemplo, Goldestein (2008, pp.76-8), Monk (1995, pp.44-5) e Smith (2007, 10.8 e 14).

${ }^{6}$ Vejamos três exemplos simples de incompatibilidade entre a explicação da filosofia que Wittgenstein faz e sua atividade filosófica nas Investigações filosóficas. No §124 do livro, Wittgenstein afirma: "A filosofia não deve, de modo algum, tocar no uso efetivo da linguagem; em último caso, pode apenas descrevê-lo. (...) A filosofia deixa tudo como está". No entanto, Wittgenstein "não hesitou em introduzir sua própria terminologia técnica ou semitécnica em filosofia (e.g. 'jogos de linguagem', 'conceito de semelhança de família', 'proposição gramatical')" (Hacker 1996, p.234). Ou seja, o próprio Wittgenstein não hesitou em tocar no uso efetivo da linguagem. Além disso, "Wittgenstein (...) parece ir contra a sua própria ideia de que a filosofia deixa tudo como está por ele mesmo propor uma concepção que não deixa tudo como está" (Snowdon 2014, p.405). Mais: no §116 Wittgenstein ressalta: "Nós reconduzimos as palavras do seu emprego metafísico para seu emprego cotidiano". Mas o emprego das palavras feito por Wittgenstein no livro, com sua terminologia técnica ou semitécnica, claramente não é seu emprego cotidiano. Por fim, vale mencionar que no §109 Wittgenstein é enfático: "Toda elucidação deve desaparecer e ser substituída apenas por descrição". As próprias Investigações filosóficas, porém, estão repletas de elucidações: "Chamarei também de 'jogos de linguagem' o conjunto da linguagem e das atividades com as quais está interligada" (§7); "O termo 'jogo de linguagem' deve aqui salientar que o falar da linguagem é uma parte de uma atividade ou de uma forma de vida (§23); "Se o sentimento dá à palavra sua significação, então 'significação' significa aqui: aquilo de que se trata" (§545), etc., etc.

${ }^{7}$ Para uma explicação desse emprego, ver, por exemplo, Goldestein (2008, capítulo 3), Nagel e Newman (2001, seção 7C) e Smith (2007, capítulo 25).

${ }^{8}$ Para a leitura completa das disputas entre Wittgenstein e Turing, ver Wittgenstein (1989).

${ }^{9}$ Para uma análise de outros aspectos do pensamento matemático wittgensteiniano que justificam o fato de que "a maioria da filosofia analítica dominante ainda parece muito escandalizada pela filosofia da matemática de Wittgenstein para considerá-la muito seriamente" (Kuusela e McGinn 2014a, p.7, n.6), ver Silva (2018). 